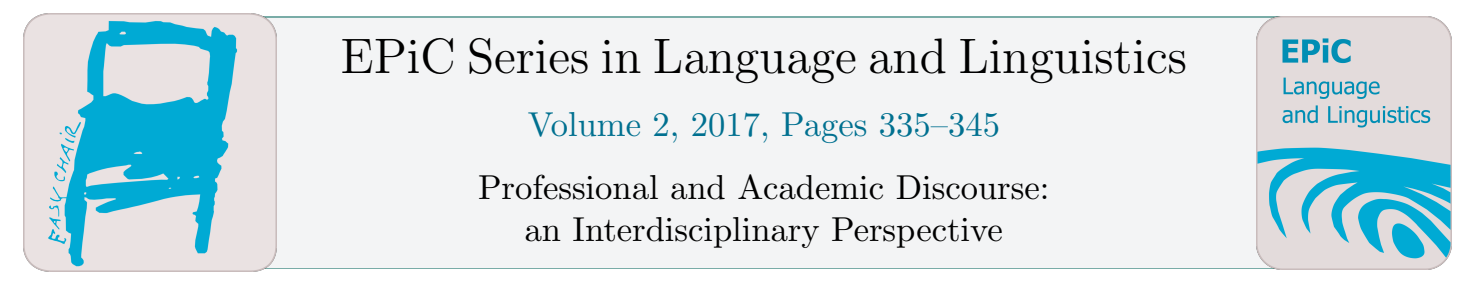

\title{
The Structure of Spanish Verbless Clauses
}

\author{
Oscar Garcia Marchena \\ University Paris Diderot \\ oscar.garcia.marchena@gmail.com
}

\begin{abstract}
The variety and profusion of verbless utterances drawn from the oral corpus CORLEC has allowed us to present a detailed classification of them. Verbless utterances with clausal content can be classified as clausal (non-elliptic) or non-clausal (elliptic) structures, also called fragments. Among the former, predicative verbless clauses are composed by a predicative head and the argument they select. This paper exposes the properties and structures of both verbless clauses and fragments found in the corpus, and analyses the syntactic and informational status of the NP selected by the predicative head of predicative verbless clauses.
\end{abstract}

\section{Introduction}

Verbless utterances constitute a highly significant part of the total of utterances in a spoken corpus of Spanish, as it is shown by Cresti and Moneglia (2005), who counts 37\% in the corpus C-ORALROM. This proportion may vary according to the genre of the corpus, as it can be seen in the different distribution of frequencies in the CORLEC corpus (Marcos-Marín, 1992), where monologic genres contain less verbless utterances than dialogic genres.

This proportion is nevertheless smaller if we leave aside verbless utterances with no propositional meaning. Interjections without arguments (1), calls (2), fillers (3) and discourse markers (4) do not express clausal meaning, and are thus different from verbless clauses, which have a non-verbal head (5), and fragments, which have an elliptical head (6) or an elliptical argument (7).

(1) ¡Oh!

(2) ¡Maria!

(3) A: -Vamos a... B: -¿casa?

A: -'Let's go...' B: - 'Home?'

(4) El tren llega a las tres, ¿verdad?

'The train arrives at three, truth?' (i.e.: 'isn’t it?')

(5) ¡Qué poca inteligencia la tuya!

'What little intelligence yours!' (i.e.: 'from you')

(6) A: -Y mira, y así nos vemos. B: -Pues entonces ¿el miércoles a las seis?

A: -'Look, this way we will see each other'. B: -'So then, Wednesday at six?' 


\section{(7) ¡Qué suerte!}

'What a luck!' (i.e.: How lucky!)

In this way, verbless clauses can be described as syntactic structures having phrastic content and a head which is not realized by a verb, but by another part of speech. Three different kinds can be found in the corpus: firstly, predicative verbless clauses, which are composed by a saturated predicate and the argument which saturates it (5); secondly, existentials, constituted by a NP which receive an existential interpretation (8); and thirdly, polars, headed by a polar adverb like sí, no, también, or tampoco ('yes, no, also, neither') (9).

(8) A:-¿¿Agustín dónde trabaja? B: -Ni idea.

A: -'Agustin, where does he work?' B: -'No idea.'

(9) Sí que hay una cosa que me molesta.

'Yes that there is a thing that disturbs me.' (i.e.: There is indeed a thing...)

Predicative verbless clauses seem therefore to constitute whole clauses by themselves, just as clauses with a verbal head do. Furthermore, certain properties suggest that they do not contain an elliptic verb, but are headed by another predicative part of speech. These properties are the following: firstly, when a verb can be reconstructed, it has no semantic content (10). Secondly, when a verb can be reconstructed, it can adopt different positions: medial like in (10) or initial like in (11). Thirdly, sometimes it is not possible to reconstruct any verb (12), (13). And fourthly, semantic content can sometimes be contributed by non-linguistic information, as it can be noted in (14), where the speaker addresses an order to the hearer. This information is nevertheless non-linguistic and cannot then be elliptical.

(10) ¡Qué bonita (es) tu camiseta!

(11) i(Es) preciosa tu falda!

(12) ¡Qué maravilla de coche!

(13) ¡Por supuesto que voy a ir a la fiesta!

(14) ¡Manos arriba!
'How beautiful (it is) your t-shirt!'

'(It is) very beautiful your skirt!'

'What a marvel of car! (i.e.: What a marvelous...)'

'Of course that I am going to the party!'

'Hands up!'

Therefore, these properties suggest that predicative verbless clauses are not elliptical, but composed by a predicative head and the argument that saturates it. This argument can be realized by a NP (10), (11), an indefinite noun (14), a clause (13) or a PP (12).

\section{Differences between Verbless Clauses and Fragments}

Verbless clauses and fragments are in this way distinguished by the presence or absence of ellipsis. Going beyond this difference, we can group the different types of verbless clauses and fragments according to their syntactic properties. This classification will allow to observe the link between both kinds of verbless utterances, and to notice the origin of their respective syntactic constraints.

\subsection{Types and Properties of Verbless Clauses}

Verbless clauses are then defined as non-elliptic syntactic structures with clausal content and a non-verbal head (or a non-finite verbal head like an infinitive or a participle). They can be of any syntactic type: declarative (13), exclamative (12), interrogative (15) or desiderative (14). They can 
also be headed by different parts of speech: a noun (12), an adjective (10), an adverb (14), a preposition (13), a non-finite verb (15) or an interjection (16).
(15) ¿Para qué esconderse?
'Why to hide?'
(16) ¡Ay si vieras!
'Oh if you knew!'

As mentioned before, verbless clauses can be classified into three types: existential, polar and predicative ones ${ }^{1}$. Predicative verbless clauses contain a predicative non-verbal head and can be further divided into evaluative, epistemic and illocutive types. Evaluative and epistemic verbless clauses are characterized by the semantic content they convey: evaluatives express an evaluation (10), (11), (12) whereas the epistemics express an epistemic judgement (13). Illocutive verbless clauses, by contrast, have a different property: they not only contain a predicative head and its argument, but they also perform an illocutive act by themselves. They can be further classified according to Searle's (1975) taxonomy of illocutionary acts: assertives (also called representatives), that inform of a state or event (17), directives, which express an order or request (14), expressives, that express a wish (18) and declarations (also called performatives), which change the state of an entity (19).
(17) ¿Y qué tal tu hija?
(18) ¡Tú, a ver si repartes!
(19) ¡Tú, castigado!

\begin{abstract}
'And what about your daughter?'
'You, to see if you share' (i.e.: Let’s see...)

'You, grounded!'
\end{abstract}

\subsection{Types and Properties of Fragments}

CORLEC corpus furnishes a prolix number of examples of fragments, which we have firstly classified according to the constituent affected by the ellipsis: fragments can have an elliptic head or an elliptic argument. Fragments with elliptic heads correspond to verbal clauses with an elliptical verbal head (20), (21). These fragments can be further distinguished by their co-reference properties: some of them contain or are constituted by a constituent which is co-referent to a segment in the source clause ${ }^{2}$. Co-referent fragments are named argumentals (20), and non-co-referent fragments, modifiers (6), repeated here as (21).

Other fragments do not have an elliptic head, but an elliptic argument. These fragments correspond to predicative verbless clauses where the selected argument is elliptic, and contain or are constituted by a non-verbal head. As expected, we find the same types that in verbless clauses: epistemic (22), evaluative (23) and illocutive fragments. Among the latter, along with presentatives (24), expressives (25), directives (26) and performatives (27), a new type is found: commisives (also known as promissives), which constitute the fifth type of Searle's (1975) illocutionary acts (28) and express an act of offer.
(20) A: -Me compré una casa en la playa. B: - ¿Una casa?
A: - 'I bought a house by the seaside.' B: -'A house?'
(21) A : -Y mira, y así nos vemos. B : -Pues entonces ¿el miércoles a las seis?
A:- 'Look, this way we will see each other'. B: -'So then, Wednesday at six?'
(22) Por supuesto.
'Of course.'

\footnotetext{
${ }^{1}$ Verbless utterances headed by a polar adverb are analyzed differently by other works. Ginzburg (2002), and Fernández and Ginzburg (2012), consider them as fragments instead of verbless clauses. Nevertheless, polar adverbs are prophrases, anaphoric to a clausal content with no elliptic content, which fits better to the definition of verbless clause.

${ }^{2}$ The source clause is defined as the structure which contains the source of the ellipsis. The fragment, which contains the ellipsis, constitutes the target clause (Reinaldo and Stainton, 2004).
} 
(23) Precioso.

(24) Encantado.

(25) Buenos días.

(26) ¡Atento!

(27) ¡Castigado!

(28) ¿Una cerveza?
'Very beautiful.'

'Delighted' (i.e.: Nice to meet you.)

'Good morning.'

‘Attentive!’ (i.e.: Pay attention!)

'Grounded!'

'Beer?'

Thus, fragments, as elliptic structures, correspond either to verbal clauses (i.e.: clauses with a finite verbal head) or to predicative verbless clauses, depending on whether the ellipsis site affects the head (in the first case) or the argument (in the second one). Furthermore, fragments with an elliptic argument correspond to a type of verbless clause (epistemic, evaluative or illocutive), whereas fragments with an elliptic head can be either co-referent (argumental) or non-co-referent (modifiers).

\subsection{Syntactic Constraints on Verbless Clauses and Fragments}

As a consequence of the syntactic differences exposed before, fragments and verbless clauses have different syntactic constraints. Concerning fragments, they seem to have few constraints. Firstly, they cannot have a subject: it is either elliptic (if the fragment has an elliptic argument) or there is no subject-head relationship (if the head is elliptic). Secondly, fragments cannot have extracted arguments (as verbless clauses do (15)), because they can only have non-verbal parts of speech as heads, and only verbs have extracted arguments.

Apart from these, fragments do not seem to have many structural constraints, as we find different syntactic structures in the corpus: head only (¿Mañana? 'Tomorrow?'), specifier - head (¿Una hora? 'One hour?'), head - adjunct (Mañana mismo 'Just tomorrow'), head - complement (A las seis 'At six') and peripheric - head (Yo a veces 'Me, sometimes'). Specifiers can easily be found in noun phrases (NP), adverb phrases (AdvP) and adjective phrases (AdjP), and adjuncts are frequent in NPs and AdjPs. As for the head - complement structure, only prepositions and argumental nouns like quantifiers can adopt this structure (Un poco de pan 'A bit of bread').

Concerning verbless clauses, the three kinds found in the corpus (existential, polar and predicative) have different constraints. Firstly, existential verbless clauses are headed by a NP, which allows all structures except head - subject and head - extraction: head only (iTierra! 'Land!'), specifier - head (Ni idea. 'No idea'), head - adjunct (vía libre. 'clear way' (i.e.: all clear!)) and head peripheric (Yo, ni idea. 'Me, no idea'). The structure head - complement is only available for quantifiers and other argumental nouns (Empate a cero. 'No-score draw').

Secondly, polar verbless clauses are headed by SAdv and can only adopt three structures: head only (29), head - peripheric (30) and head - adjunct (31). Thirdly, predicative verbless clauses are constructed with the three structures which allow expressing the argument selected by the predicative head: head - subject (32), head - complement (33), (35) and head - peripheric (34). The structure head - complement is available for heads taking clausal complements, as in the example, and for predicative (evaluative) nouns selecting their argument as a PP headed by de (35) (indicated in bold).

(29) Sí. 'Yes'

(30) Yo no. 'Me not' (i.e.: I don't)

(31) Si quieres, sí. 'If you want, yes’ (i.e.: If you want, OK)

(32) Precioso tu vestido. 'Very beautiful your dress' (i.e.: Nice dress)

(33) Seguro que no va a venir. 'Sure he won’t come.' 
(34) El vestido, precioso. 'The dress, very beautiful'

(35) Qué maravilla de ciudad. 'What marvel of city’ (i.e.: What a marvelous city)

Therefore, the analysis of the structural constrains of verbless clauses and fragments reveal that fragments, as polar and existential verbless clauses, inherit the structural constraints imposed by the part of speech of the head, whereas predicative verbless clauses inherit the constraints of the clausal structure, which requires both a predicative head and its saturating argument.

\section{The Function of the NP in Predicative Verbless Clauses}

As we have seen above, predicative verbless clauses can be formed by a head accompanied by a NP, for which we have proposed two syntactic functions: subject (32) and peripheric (34), (36), but how can we determine this function? Subjects and peripherics have different properties: subjects are selected by the head and saturate its valence, whereas peripherics are not necessarily selected by it and do not saturate its valence (36). Therefore, in examples like (36) it is clear that the head does not select the NP, so the NP has the function of peripheric.

Nevertheless, when the NP is co-referent to an argument selected by the head (34), (37), it could be the subject or a peripheric. In these cases it is not straightforward to distinguish whether the NP is the selected subject or a dislocated argument, which is analyzed as a peripheric. In these cases a deeper analysis is required to determine whether the NP preceding the head is its subject or a peripheric.

(36) Yo a veces.

(37) Yo encantado.
'Me, sometimes'

'Me, delighted' (i.e.: Me, with pleasure.)

In order to determine the function of the NP it is necessary to check the NP properties in two steps. On the one hand, we have to determine whether the NP corresponds to an argument selected by the head or not: if it is not, the NP is clearly a peripheric; but if it is, the NP could be a subject (selected by the head) or a peripheric (co-referent to the argument selected by the head). On the other hand, if the NP corresponds to a selected argument, we have to verify if the properties of the NP are those of a subject or of a dislocated phrase.

\subsection{Is it Selected by the Head?}

In order to verify whether the NP is selected by the head or not, we analyze the selectional properties of the heads in every type of predicative verbless clause: evaluative, epistemic, presentative, expressive, directive and performative.

Firstly, we observe that in evaluative verbless clauses, the head can select either a clause (38) or an entity (32). If it selects an entity, the NP is clearly selected by the head (32), but if it selects a clause and it is preceded by a NP (39), the NP does not correspond to the argument selected by the head, since the head selects a whole clause and not only the portion expressed by the NP. In this case, the NP is not a selected argument, and it is therefore a peripheric. Secondly, epistemic verbless clauses only select clauses (40), so any NP preceding the head will be a peripheric (41).

(38) Que venga Maria, estupendo.

(39) Maria, estupendo.

(40) Tú seguro que vas a aprobar el examen.

(41) Tú seguro.
'That Maria comes, great!' (i.e.: It is great that...)

'Maria, great!'

'You, sur that you will pass the exam.'

'You for sure!' 
Thirdly, representative verbless clauses always select an entity, presented as a full (third person) NP (42) or a first or second person pronoun (37). In both cases the NP is selected by the head. Representatives, as the rest of illocutive verbless clauses, can be analyzed as having a more complex semantic structure, where the main predicate is realized by the speech act, and the participants and the verbless clause itself constitute the arguments. Under this analysis, the full semantic content of the representative verbless clause (37) could be paraphrased as follows: The speaker informs the hearer that he is delighted (to meet to hearer). In this way, even if the predicate expressed by the verbless clause is not the main predicate expressed, it is an embedded predicate in the semantic structure, and it selects an argument.

Fourthly, expressive verbless clauses display the same pattern: the NP can either express a third person (43) or a first or second person pronoun (44), which is in every case selected by the head. Fifthly, the head of directive verbless clauses also select the preceding NP, headed by a pronoun (45) or a noun (46). ${ }^{3}$ Lastly, perfomative verbless clauses follow the pattern of the rest of illocutive verbless clauses: they select the preceding NP, headed by a pronoun (47) or a noun (48).

(42) La vencedora, la francesa.

(43) Tú, a vivir que son dos días.

(44) Los jóvenes, a cumplir 100 años

(45) ¡Tú, atención!

(46) La camisa por dentro.

(47) ¡Tú, castigado!

(48) ¡Trato hecho!
'The winner, the French girl'

'You, to live, that there are two days'

'Young people, to make 100 years' (i.e.: let’s...)

'You, attention!'

'Shirt inside!'

'You grounded!'

'Deal done!' (i.e.: Deal!)

In conclusion, only two kinds of verbless clauses do not select a preceding NP: epistemic ones (which always select a clause as their argument) and those evaluatives that select a clause. In these cases, the preceding NP is clearly a peripheric (called non-predicative peripheric). In contrast, evaluatives selecting an entity and illocutive verbless clauses do always select the content of the preceding NP, which may be their subject, or a peripheric, if the NP denoting the subject is dislocated.

\subsection{Is it a Subject or a Peripheric?}

Once it has been made clear which NPs are actually selected by the head of a verbless clause, we have to check their syntactic properties in order to determine whether the NP has the function of subject or peripheric. Fortunately, subjects and peripherics can be distinguished by two properties: uniqueness and word order (Laurens, 2008). Subjects are unique and have a fixed position, whereas peripherics are accumulative and can appear in different positions. These properties are illustrated by the clauses with a verbal head in (49) - (51): when two or more NPs are accumulated before the head, it is the NP closest to the head that is interpreted as the subject. The other NPs are therefore peripherics.

(49) Juan, el director lo vio ayer.

(50) El director, Juan lo vio ayer.
'Juan, the director, saw him yesterday.'

'The director, Juan, saw him yesterday.'

\footnotetext{
${ }^{3}$ Directives having an abstract argumental noun as a head (45) clearly seem to select the pronoun as an argument, as it can be seen in the ability of these nouns to express it as an argument in a NP (Tu atención hacia el detalle. 'Your attention to detail'). It may seem less clear whether concrete nouns in idiomatic uses do select a preceding pronoun or not ( $¡$ Tú, ojo! 'You, eye!' (i.e.: You, attention!)). The fact that these nouns can also express the pronoun as an argument in a NP suggest that they do select the pronoun as an argument (Tu ojo para los negocios. 'Your eye for bussiness').
} 
(51) Luis Rodríguez, el director, Juan lo vio ayer.

'Luis Rodríguez, the director, Juan saw him yesterday.'

We propose the following test to identify the subject in verbless clauses: to construct verbless clauses with two NPs preceding the head and to vary their order. If a given NP cannot be moved or accumulated without change of meaning, then it can be identified as the subject. If the meaning does not change after the modification of word order, or the resulting clause is not grammatical, then the NP is a peripheric.

\subsection{Classification of NP by their Syntactic Properties}

The typology of verbless clauses presented here is based on their semantic (epistemic, evaluative) and pragmatic properties (the speech act realized by illocutive verbless clauses: representative, expressive, directive or performative), but we also find syntactic regularities in them. All verbless clauses can be classified as having one of these five patterns:

- Initial head and fixed word order

- Initial head and variable word order

- Final head and indefinite NPs

- Final head and variable order

- Head selects a participant

- Head selects a definite (third person) NP

Only one type of verbless clauses has the first pattern: a subtype of expressives known as desideratives. Their head occupies an initial position and their word order is fixed (52). Two types of verbless clauses can adopt the second pattern (initial head and variable word order): evaluatives (53) and directives (54). The third pattern (final head and indefinite NP) can be found in directives (55) and performatives (56). The fourth pattern (final head and variable order) is present in evaluatives (57) and directives (58), and can be recognized as the result of word order variation of the second pattern. Therefore, (53) and (57) on the one hand, and (54) and (58) in the other one, are two syntactic realizations of one single type of verbless clause.

(52) Felices los pobres.

(53) Preciosa la falda.

(54) ¡Quietas las manos!

(55) ¡Manos arriba!

(56) Trato hecho.

(57) La falda, preciosa.

(58) ¡Las manos, quietas!
'Happy the poor' (i.e.: Blessed be the poor.)

'Very beautiful the skirt.' (i.e.: beautiful skirt.)

'Still the hands!' (i.e.: Hands off!)

'Hands up!'

'Deal done'

'The skirt, very beautiful.'

'The hands, still.' (i.e.: Hands off!)

The fifth pattern, corresponding to verbless clauses where the head selects a participant, can be found in all types of illocutive verbless clauses: representatives (37), expressives (43), directives (45) and performatives (47). Finally, the sixth pattern, where the head selects a NP denoting a third person, can be found in performatives (59) and expressives, that can be either head-initial (60) or head-final (61). 
(59) Los niños, castigados.

(60) ¡A vivir mucho los jóvenes!

(61) ¡Los jóvenes, a vivir!
'The children, grounded.'

'To live long, the young people!' (i.e.: Let's...)

'The Young people, to live!’ (i.e.: Let’s...)

\subsection{Testing whether the NP has Subject or Peripheric Properties}

Once the different types of verbless clauses have been grouped according to their syntactic patterns, we apply the test to the verbless clauses in every pattern in order to check whether the NP has the properties of a subject or of a peripheric. Expressive desiderative verbless clauses (52), which display the first pattern, cannot vary their word order without change of meaning, and the result may be difficult (62), (63). Nevertheless, a NP can be placed before the head (64). These results indicate that the final NP is the subject, and initial NPs are peripherics.

(62) \#Felices los pobres, las cosechas.

(63) \#Felices las cosechas, los pobres.

(64) Las cosechas, felices los pobres.

(65) Fuera los zapatos, barro en los pies.

(66) Fuera barro en los pies, los zapatos.

(67) Barro en los pies, casa ajena, fuera los zapatos.

'Mud in the feet, someone else's house, shoes off.'

(68) Los que estén de acuerdo, manos arriba.

(69) *Manos, los que estén de acuerdo arriba.

(70) Tu hermana, la falda, preciosa.

(71) La falda, tu hermana, preciosa.

(72) Yo, para mi pueblo, el monorraíl, de maravilla.

'Me, for my village, the monorail, great!

(73) ¡Tú, el que ha causado este desastre, castigado!

'You, who provoked this mess, grounded!'

(74) ¡El que ha causado este desastre, tú, castigado!

'Who provoked this mess, you, grounded!'

(75) Los españoles, los jóvenes, ja vivir de los padres!

'Spanish people, the young ones, to live on their parents!'

(76) Los jóvenes, los españoles, ¡a vivir de los padres!

'Young people, Spanish, to live on their parents!'

Concerning the second pattern (initial head and variable order) (53), (54), it can be observed on the one hand, that a variation of the order of two accumulated NPs entails a variation of meaning (65) - (66); and on the other hand, that pre-nuclear NPs can be accumulated (67). These properties indicate that the post-nuclear NP is the subject, whereas pre-nuclear NPs are peripherics. Verbless clauses 
having the third pattern (final head and selection of an indefinite NP) (55), (56) cannot vary the order of the NP (68) - (69), which suggest that the NP is the subject, although they can have peripherics in the left (68).

The cases of verbless clauses with the fourth pattern (final head and variable order) (57), (58) can accumulate NPs before the head without clear identification of which NP corresponds to the selected argument (70), (71). Accumulated NPs are also found split (72). These properties suggest that these NPs are peripheric.

Examples with the fifth pattern (where the head selects a participant) (45), (47) can freely accumulate and vary the order of the preceding NPs (73) - (74), which indicates that they are peripherics. Finally, verbless clauses having the sixth pattern (where the head selects a definite NP) (59), (60), (61) can vary the order of the preceding NPs, which suggests that they are also peripherics (75), (76).

\subsection{Results}

The results of the test presented above allows us to associate every syntactic pattern to a structure head - subject or head - peripheric, as it is illustrated by table 1 below $^{4}$. The first three patterns, with an initial head (52), (53) or a final head and undefined NP (55) display a head - subject structure, whereas the last three patterns have a head - peripheric structure.

Several conclusions can be drawn from these data. First, there is one particular type of verbless clause, the expressive desiderative, with a head - subject structure, with initial head and fixed order (52). Second, evaluatives and directives with a full NP have a subject in post-nuclear position, that can be left-dislocated (53), (54) - (57), (58). Third, directives and performatives can adopt a subject head structure with a pre-nuclear indefinite noun. Fourth, pronouns (which denote participants) are always peripherics; and fifth, performatives and expressives selecting a full third person NP have a head - peripheric structure.

\footnotetext{
${ }^{4}$ In Table 1, Hd: head; 1p: first person; 2p: second person; 3p: third person
} 


\begin{tabular}{|c|c|c|c|}
\hline Properties & Verbless clauses & Hd - sujet & Hd - peripheric \\
\hline Initial head and fixed order & Expressives & + & \\
\hline \multirow[t]{2}{*}{ Initial head and variable order } & Evaluatives & + & \\
\hline & Directives & + & \\
\hline \multirow[t]{2}{*}{ Final head and indefinite NP } & Directives & + & \\
\hline & Performatives & + & \\
\hline \multirow[t]{2}{*}{ Final head and variable order } & Evaluatives & & + \\
\hline & Directives & & + \\
\hline \multirow[t]{4}{*}{ Selecting a participant } & Representatives 1p & & + \\
\hline & Expressives 2p & & + \\
\hline & Directives $2 p$ & & + \\
\hline & Performatives 2p & & + \\
\hline \multirow[t]{3}{*}{ Definite 3p NP } & Performatives & & + \\
\hline & Head initial expressives & & + \\
\hline & Head final expressives & & + \\
\hline
\end{tabular}

Table 1: Mapping syntactic structure - syntactic patterns of verbless clauses

\section{Mapping Syntactic and Informative Structures}

Mapping the syntactic patterns with the syntactic structures obtained from the tests has allowed us to note the different syntactic configurations of verbless clauses. These different configurations seem to be motivated by different information structures. Firstly, it can be observed that verbless clauses with final subjects have a focus - background structure (Lambrecht, 1994), as we can see in the examples of expressive desideratives (77), evaluatives and directives (78). In these cases, the head has informative prominence, unlike the subject, which can even be elliptic ${ }^{5}$. This possibility of ellipsis can be explained by its informational status of background.

Secondly, directives and performatives with initial subject and an indefinite NP (79) have no informational background, since the whole structure has informational prominence. Therefore, they seem to have an all-focus structure, which would motivate the indefinite NP. Thirdly, head peripheric structures (like those found in evaluatives and directives with dislocated subjects; in illocutives that select a pronoun; and in performatives and expressives with a full NP) (80) are correlated with topic - comment informational structures. The peripheric argument corresponds then to a dislocated topic.

(77) Felices los pobres.

(78) Arriba las manos.

(79) ¡Manos arriba!

(80) Los niños, castigados.
'Blessed (be) the poor!'

'Up the hands.'

'Hands up!'

'The children, grounded!'

\footnotetext{
${ }^{5}$ Desiderative expressives (Felices los pobres. 'Blessed the poor') cannot have an elliptic subject though. This exception may be explained by the fact that these structures are no longer productive in Spanish or are restricted to particular contexts.
} 
These four examples correspond then to the fourth possible mappings of syntactic and informational structures: final subject and focus - background (77), (78); initial subject and all focus (79); and finally, head - peripheric and topic - comment (80).

\section{Conclusion}

The observation and classification of the totality of verbless structures in the oral corpus CORLEC has allowed us to observe their syntactic variety: they can be either elliptic (fragments) or non-elliptic (verbless clauses), and both types have different syntactic constraints. Both types can be constituted by a variety of syntactic types and structures, and be headed by a diversity of parts of speech. Besides, they can be classified by their semantic and pragmatic properties.

The predicative head of verbless structures can be accompanied by a NP, which can constitute either its subject or a peripheric, depending on the syntactic properties of the NP. Furthermore, the different syntactic structures (head - subject, head - peripheric, etc.) seem to correlate with different informative structures, like focus - background or topic - comment.

\section{References}

Cresti, E., Moneglia, M. (eds.) (2005) C-ORAL-ROM Integrated Reference Corpora for Spoken Romance Languages. Amsterdam: John Benjamins. p. 135-161.

Fernández, R. and J. Ginzburg (2002). Non-sentential utterances: A corpus study. Traitement Automatique des Languages: Dialogue 43 2, p. 13-42.

Ginzburg, J. (2012). The interactive stance. Oxford University Press.

Lambrecht, K. (1994). Information Structure and Sentence Form: Topic, Focus, and the Mental Representations of Discourse Referents. Cambridge University Press.

Laurens, F. (2008). French Predicative Verbless Utterances. In Stefan Muller (Ed.): Proceedings of the 15th International Conference on Head-Driven Phrase Structure Grammar, National Institute of Information and Communications Technology, Keihanna p.152-172. Stanford, CA: CSLI Publications.

Marcos-Marín, F. (1992). Corpus de referencia de la lengua española contemporánea: Corpus oral peninsular. Technical report, Universidad Autónoma de Madrid.

Reinaldo E. and Stainton R. J. (2004). Introduction. In R. Elugardo and R. J. Stainton (eds.), Ellipsis and Nonsentential Speech, p. 1-26. Dordrecht: Kluwer.

Searle, J. (1975), “A Taxonomy of Illocutionary Acts”, in: Günderson, K. (ed.), Language, Mind, and Knowledge, (Minneapolis Studies in the Philosophy of Science, vol. 7), University of Minneapolis Press, p. 344-369 